\title{
DNA as genetic material and as a nutrient in halophilic Archaea
}

\begin{abstract}
Aharon Oren *
Department of Plant and Environmental Sciences, The Institute of Life Sciences, The Hebrew University of Jerusalem, Jerusalem, Israel

*Correspondence: aharon.oren@mail.huji.ac.il
\end{abstract}

Edited by:

Jesse Dillon, California State University, Long Beach, USA

Reviewed by:

Juergen Wiegel, University of Georgia, USA

Keywords: Haloferax, DNase, phosphate, polyploidy, DNA

\section{A commentary on}

Extracellular DNA metabolism in Haloferax volcanii

by Chimileski, S., Dolas, K., Naor, A., Gophna, U., and Papke, R. T. (2014). Front. Microbiol. 5:57. doi: 10.3389/fmicb.2014.00057

Phosphorus is a key element for life, and in many ecosystems phosphate is the limiting nutrient. This is also true for many hypersaline ecosystems. A wellknown example is the Dead Sea, where the possibility of massive development of microbial blooms is determined by the excessively high concentrations of magnesium and calcium and phosphate is the limiting inorganic nutrient, not only for the alga Dunaliella but also for the halophilic Archaea in blooms that occasionally develop in the lake when conditions become favorable (Oren, 1983). It is therefore not surprising that members of the Halobacteriaceae have developed mechanisms to use not only phosphate ions but other phosphorus sources as well. Thus, the square archaeon Haloquadratum walsbyi possesses a gene cluster that allows uptake of phosphonates and cleavage of the stable carbon-phosphorus bond (Bolhuis et al., 2006).

DNA contains $10 \%$ phosphorus by weight. Many halophilic Archaea have discovered the advantage of DNA as a phosphorus storage polymer: they are commonly polyploid: some species may contain up to 30 genome copies (Breuert et al., 2006; Soppa, 2013; Zerulla and Soppa, 2014). Polyploidy was documented in Halobacterium salinarum, Haloferax mediterranei, and Haloferax volcanii. Cell sorting of prokaryotes from saltern brines provided further evidence for polyploidy (Zhaxybayeva et al., 2013). When $H f x$. volcanii cells are starved for phosphorus, the number of genome copies is reduced from $\sim 30$ to $\sim 2$, allowing for about three additional cell division cycles. The degree of ploidy is thus determined by the level of available nutrients. The number of ribosomes is not decreased, showing that rRNA does not serve as a phosphorus reserve. In non-starved cells the amount of DNA-bound phosphorus is about twice that found in the ribosomes, making DNA more suitable as phosphorus storage material (Zerulla et al., 2014). The stable storage of phosphate was even proposed as a driving force for the emergence of DNA in early evolution before it took over the function of genetic information carrier from RNA (Zerulla and Soppa, 2014; Zerulla et al., 2014).

Another way to obtain phosphorus is by degrading DNA outside the cells. Extracellular DNA is found in all environments, including hypersaline ones (Chimileski et al., 2014). The ability to degrade extracellular DNA is seldom tested during characterization of halophilic Archaea isolates. The proposed minimal standards for description of new taxa of Halobacteriales (Oren et al., 1997) include tests for amylase, protease and lipase but not DNAse. There are only few studies where isolates were tested for hydrolytic activity on highsalt DNA-containing agar. Nearly half of 293 archaeal strains isolated from an Iranian salt lake tested positive for DNA degradation; most were Halorubrum spp. (Makhdoumi Kakhki et al., 2011). Two out of six representative isolates from Tuz
Lake, Turkey and the adjacent salterns- $\mathrm{a}$ Halorubrum and a Halobacterium showed the activity (Birbir et al., 2007), as did two Halogeometricum-affiliated isolates from salterns of Tamil Nadu, India (Manikandan et al., 2009). The nature of the enzyme(s) with extracellular DNase activity in Halobacteriaceae was never ascertained. An ISI Web of Science search did not yield any papers dedicated to the properties of haloarchaeal DNases.

Mechanisms of degradation of DNA to be used as a nutrient and to be taken up as a source of new genes may be related (Finkel and Kolter, 2001). Horizontal transfer of genetic material is known for a number of halophilic Archaea. In the genus Haloferax mating systems are based on direct contact between cells of the same species (Rosenshine et al., 1989) and even of different species, leading to the formation of recombinant hybrids (Naor et al., 2012). Genetic recombination with extensive gene exchange occurs within natural populations of Halorubrum (Papke et al., 2004, 2007), but the underlying mechanism is still unknown. Evidence for the transfer of large sections of DNA between phylogenetically disparate members of the Halobacteriaceae came from a metagenomic study in Deep Lake, an Antactic hypersaline lake. The four organisms dominating the community and belonging to different genera share contiguous up to $35-\mathrm{kb}$ long regions of $\sim 100 \%$ identity (DeMaere et al., 2013).

In a recent "Frontiers in Microbiology" paper, Chimileski et al. (2014) studied extracellular DNA metabolism in $H f x$. volcanii. They showed that exogenous double-stranded DNA can be used as a nutrient to supply essential phosphorus. 
Not all sources of DNA are equally suitable, and there is a large degree of specificity involved. DNA of the same species supports growth, but herring sperm DNA or Escherichia coli DNA were not effective. However, unmethylated E. coli DNA was metabolized. Thus, there is a bias against highly divergent methylated DNA.

The gene Hvo_1477 was identified as a factor likely involved in DNA processing at the cell surface. It is the first identified archaeal extracellular DNA processing / uptake-related gene. Its deletion created a strain unable to grow on extracellular DNA. Hvo_1477 homologs are commonly found in genomes of Halobacteriaceae and other Archaea. Hvo_1477 codes for a 327 amino acid lipoprotein attached to the membrane, homologous with known Bacillus and Staphylococcus nucleases.

Use of DNA as a nutrient may be considered a form of natural DNA uptake or natural competence. However, natural competence requires internalization of intact DNA fragments and the presence of a complex molecular machine for binding and intracellular processing of DNA. Import of high-molecularweight DNA through membranes of halophilic Archaea is yet to be conclusively demonstrated.

The data presented have important implications for different disciplines including microbial ecology, nutrition, and evolution. They raise some intriguing questions:

- To what extent is extracellular DNA exploited as a phosphorus source in natural communities of Halobacteriaceae?

- If the sole purpose of DNA uptake by $H f x$. volcanii were the sequestering of phosphorus to avoid starvation, why are not all types of DNA taken up with equal efficiency?

- If DNA can be internalized, how does the cell decide whether to degrade it as a source of nutrient or explore the possibility that it may encode useful genetic material?

The study by Chimileski et al. may thus lead to basic new insights in more than one field of microbiology.

\section{REFERENCES}

Birbir, M., Calli, B., Mertoglu, B., Elevi Bardavid, R., Oren, A., Ogmen, M. N., et al. (2007). Extremely halophilic Archaea from Tuz Lake, Turkey, and the adjacent Kaldirim and Kayacik salterns. World J. Microbiol. Biotechnol. 23, 309-316. doi: 10.1007/s11274-006-9223-4

Bolhuis, H., Palm, P., Wende, A., Falb, M., Rampp, M., Rodriguez-Valera, F., et al. (2006). The genome of the square archaeon Haloquadratum walsbyi: life at the limits of water activity. BMC Genomics 7:169. doi: 10.1186/1471-2164-7-169

Breuert, S., Allers, T., Spohn, G., and Soppa, J. (2006). Regulated polyploidy in halophilic archaea. PLoS ONE 1:e92. doi: 10.1371/journal.pone. 0000092

Chimileski, S., Dolas, K., Naor, A., Gophna, U., and Papke, R. T. (2014). Extracellular DNA metabolism in Haloferax volcanii. Front. Microbiol. 5:57. doi: 10.3389/fmicb.2014.00057

DeMaere, M. Z., Williams, T. J., Allen, M. A., Brown, M. V., Gibson, J. A. E., Rich, J., et al. (2013). High level of intergenera gene exchange shapes the evolution of haloarchaea in an isolated Antarctic lake. Proc. Natl. Acad. Sci. U.S.A. 110, 16939-16944. doi: 10.1073/pnas/pnas.1307090110

Finkel, S. E., and Kolter, R. (2001). DNA as a nutrient: novel role for bacterial competence gene homologs. J. Bacteriol. 183, 6288-6293. doi: 10.1128/JB.183.21.6288-6293.2001

Makhdoumi Kakhki, A., Amoozegar, M. A., and Mahmodi Khaledi, E. (2011). Diversity of hydrolytic enzymes in haloarchaeal strains isolated from salt lake. Int. J. Environ. Sci. Tech. 8, 705-714. doi: 10.1007/BF03326255

Manikandan, M., Kannan, V., and Pašić, L. (2009). Diversity of microorganisms in solar salterns of Tamil Nadu, India. World J. Microbiol. Biotechnol. 25, 1007-1017. doi: 10.1007s11274-009-9980-y

Naor, A., Lapierre, P., Mevarech, M., Papke, R. T., and Gophna, U. (2012). Low species barriers in halophilic archaea and the formation of recombinant hybrids. Curr. Biol. 22, 1444-1448. doi: 10.1016/j.cub.2012.05.056

Oren, A. (1983). Population dynamics of halobacteria in the Dead Sea water column. Limnol. Oceanogr. 28, 1094-1103. doi: 10.4319/lo.1983.28.6.1094
Oren, A., Ventosa, A., and Grant, W. D. (1997). Proposal of minimal standards for description of new taxa in the order Halobacteriales. Int. J. Syst. Bacteriol. 47, 233-238. doi: 10.1099/0020771347-1-233

Papke, R. T., Koenig, J. E., Rodriguez-Valera, F., and Doolittle, W. F. (2004). Frequent recombination in a saltern population of Halorubrum. Science 306, 1928-1929. doi: 10.1126/science.1103289

Papke, R. T., Zhaxybaeeva, O., Feil, E. J., Sommerfeld, K., Muise, D., and Doolittle, W. F. (2007). Searching for species in haloarchaea. Proc. Natl. Acad. Sci. U.S.A. 104, 14092-14097. doi: 10.1073/pnas.0706358104

Rosenshine, I., Tchelet, R., and Mevarech, M. (1989). The mechanism of DNA transfer in the mating system of an archaebacterium. Science 245 , 1387-1389. doi: 10.1126/science. 2818746

Soppa, J. (2013). Evolutionary advantages of polyploidy in halophilic Archaea. Biochem. Soc. Trans. 41, 339-343. doi: 10.1042/BST/BST212013-150

Zerulla, K., Chimileski, S., Näther, D., Gophna, U., Papke, R. T., and Soppa, J. (2014). DNA as a phosphate storage polmer and the alternative of polyploidy for growth or survival. PLOS ONE 9:e941819. doi: 10.1371/journal.pone.0094819

Zerulla, K., and Soppa, J. (2014). Polyploidy in haloarchaea: advantages for growth and survival. Front. Microbiol. 5:274. doi: 10.3389/fmicb.2014.00274

Zhaxybayeva, O., Stepanauskas, R., Mohan, N. R., and Papke, R. T. (2013). Cell sorting analysis of geographically separated hypersaline environments. Extremophiles 17, 265-275. doi: 10.1007/s00792013-0514-Z

Conflict of Interest Statement: The author declares that the research was conducted in the absence of any commercial or financial relationships that could be construed as a potential conflict of interest.

Received: 24 September 2014; accepted: 26 September 2014; published online: 14 October 2014.

Citation: Oren A (2014) DNA as genetic material and as a nutrient in halophilic Archaea. Front. Microbiol. 5:539. doi: 10.3389/fmicb.2014.00539

This article was submitted to Extreme Microbiology, a section of the journal Frontiers in Microbiology.

Copyright (c) 2014 Oren. This is an open-access article distributed under the terms of the Creative Commons Attribution License (CC BY). The use, distribution or reproduction in other forums is permitted, provided the original author(s) or licensor are credited and that the original publication in this journal is cited, in accordance with accepted academic practice. No use, distribution or reproduction is permitted which does not comply with these terms. 